\title{
Pharmacokinetics of Mirodenafil, a New Erectogenic, and its Metabolite, SK3541, in Rats: Involvement of CYP1A1/2, 2B1/2, 2D Subfamily, and $3 A 1 / 2$ for the Metabolism of Both Mirodenafil and SK3541
}

\author{
Young Hee Choi ${ }^{1,2}$, Young Sun Lee ${ }^{1}$, Myung Gull Lee ${ }^{1}$, Tae Kon Kim ${ }^{3}$, Bong-Yong Lee ${ }^{3}$ \\ ${ }^{1}$ College of Pharmacy and Research Institute of Pharmaceutical Sciences, Seoul National University, Seoul, South \\ Korea \\ ${ }^{2}$ Department of Medical Biotechnology, College of Life Science and Biotechnology, Dongguk University-Seoul, Seoul, \\ South Korea \\ ${ }^{3}$ Life Science Research Center, SK Chemicals, Suwon, South Korea
}

Received, September 16, 2009; Revised, February 2, 2010; Accepted, March 31, 2010; Published, April 14, 2010.

\begin{abstract}
ABASTRACT. Purpose. This study was performed to find which types of hepatic CYP isoforms are responsible for the metabolism of mirodenafil (a new erectogenic) and one of its metabolite, SK3541, using various hepatic CYP inducers and inhibitors in rats. Methods. Mirodenafil at a dose of $20 \mathrm{mg} / \mathrm{kg}$ was administered intravenously in control rats and rats pretreated with various CYP inducers and inhibitors. The disappearance of SK3541 was also measured in vitro hepatic microsomes of rats with and without CYP inducers and inhibitors. Results. Compared with controls, in rats pretreated with 3-methylcholanthrene, orphenadrine, and dexamethasone (main inducers of CYP1A1/2, 2B1/2, and 3A1/2, respectively), the nonrenal clearances $\left(\mathrm{CL}_{\mathrm{NR}} \mathrm{S}\right)$ of mirodenafil were significantly faster (by 39.4, 59.3, and 63.9\%, respectively). However, compared with controls, in rats pretreated with quinine and troleandomycin (main inhibitors of CYP2D subfamily and $3 \mathrm{~A} 1 / 2$, respectively), the $\mathrm{CL}_{\mathrm{NR}} \mathrm{S}$ of mirodenafil were significantly slower (by 36.1 and $33.2 \%$, respectively). In rat hepatic microsomes spiked with furafylline, quinine, and troleandomycin (main inhibitors of CYP1A2, 2D subfamily, and 3A1/2, respectively), the intrinsic clearances $\left(\mathrm{CL}_{\mathrm{int}} \mathrm{s}\right)$ for the disappearance of SK3541 were significantly slower (by 18.4, 35.3, and 51.5\%, respectively) than controls. Also in rat hepatic microsomes pretreated with orphenadrine (a main inducer of CYP2B1/2), the $\mathrm{CL}_{\text {int }}$ for the disappearance of SK3541 was significantly faster (by 55.5\%) than controls. Conclusions. The above data suggest that hepatic CYP1A1/2, 2B1/2, 2D subfamily, and 3A1/2 are involved in the metabolism of both mirodenafil and SK3541 in rats.
\end{abstract}

\section{INTRODUCTION}

Male erectile dysfunction, the present inability to achieve or maintain an erection for satisfactory sexual performance, is a common and important medical problem (1). Recently, the phosphodiesterase type 5 (PDE-5) inhibitors are used to improve male erectile dysfunction by binding cyclic guanosine monophosphate and maintaining sufficient cellular levels in the smooth muscles (2). Thus, mirodenafil (SK3530), 5ethyl-2-\{5-[4-(2-hydroxyethyl)piperazine-1sulfonyl]-2-phenyl $\}-7$-propoxypropyl-3,5-dihydropyrrolo-[3,2- $d]$-pyrimidin-4-one, has been developed to alleviate drawbacks of common side effects of PDE-5 inhibitors, such as headache, flushing, nasal congestion, and dyspepsia (3). Mirodenafil was recently marketed in South Korea as $\operatorname{Mvix}^{\circledR}$ (100 mg tablet; SK Chemicals, Seoul,
South Korea) for the treatment of male erectile dysfunction.

Rat liver microsomal studies have shown that mirodenafil was converted to eleven metabolites (Figure 1) including SK3541 (5-ethyl-2-(5(piperazin-1-sulfonyl)-2-n-propoxyphenyl)-7-npropyl-3,5-dihydro-4H-pyrrolo-[3,2- $d$ ]-pyrimidin4-one) and SK3544 (2-(4-(3-(5-ethyl-7-n-propyl3,5-dihydro-4H-pyrrolo[3,2- $d]$ pyrimidin-4-onyl)-4$n$-propoxyphenyl ) sulfonylpiperazin-1-yl ) ethyl hydrogen sulfate; a sulfate conjugate of mirodenafil) (4).

Corresponding Author: Myung G. Lee, College of Pharmacy and Research Institute of Pharmaceutical Sciences, Seoul National University, San 56-1, Shinlim-Dong, Kwanak-Gu, Seoul 151-742, South Korea, leemg@snu.ac.kr 
SK3541 was further metabolized to nine metabolites (4). The $\mathrm{IC}_{50} \mathrm{~s}$ of mirodenafil (0.338 $\mathrm{nM})$ and SK3541 (3 nM) for the inhibition of PDE5 were lower than that of other PDE-5 inhibitors, such as sildenafil $(3.7 \mathrm{nM})$ and tadalafil $(6.7 \mathrm{nM})$, but SK3544 has not PDE-5 inhibitory activity (an internal report).

Thus, the pharmacokinetics of mirodenafil and SK3541 were evaluated in the present study. In vitro human liver microsomal studies have shown that cytochrome P450 (CYP) 3A4 was the major enzyme and CYP2C8 was a minor enzyme for the $\mathrm{N}$-dealkylation of mirodenafil (5), but the studies on humans in vivo did not reported yet. Thus, this study was performed to find hepatic CYP isoforms responsible for the metabolism of mirodenafil and SK3541 in vivo and in vitro using various hepatic CYP inhibitors and/or inducers in rats. Although the rat results can not predict well the human results (6), the homology between rat and human CYP isozymes has been reported (7).

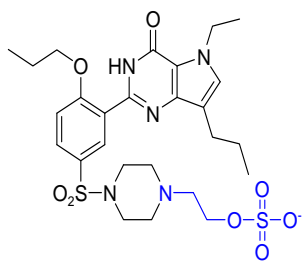

Exact Mass: 610.20

SK 3544

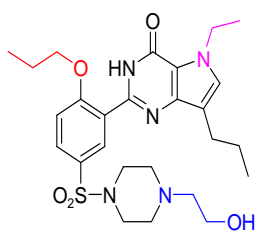

Exact Mass: 531.25
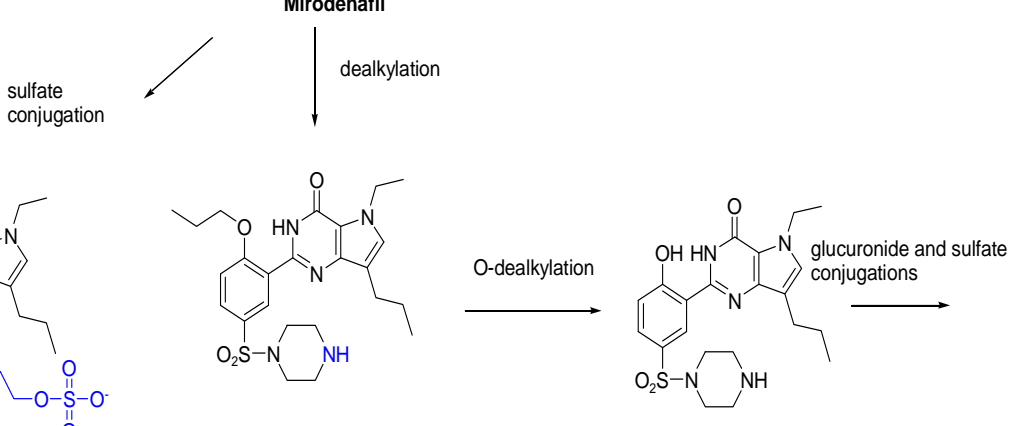

Exact Mass: 487.23

SK 3541

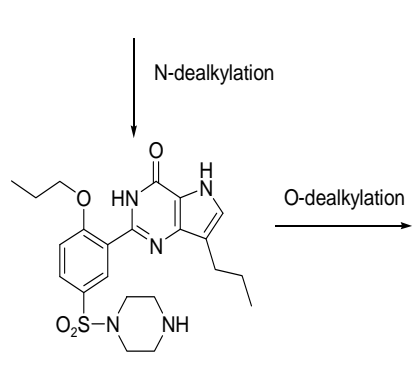

Exact Mass: 459.19

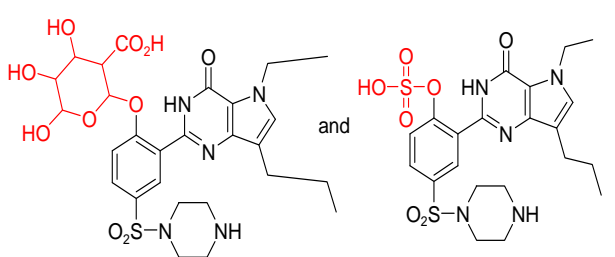

Exact Mass: 621.21

Exact Mass: 525.14

$\mathrm{N}$-dealkylation

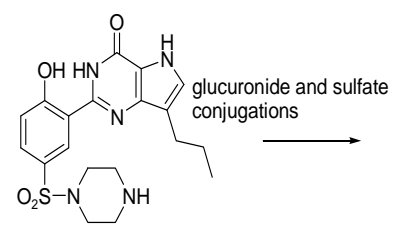

Exact Mass: 417.15

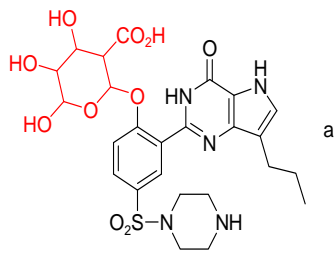

Exact Mass: 593.18

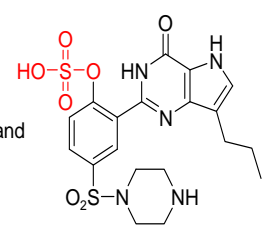

hydrolysis

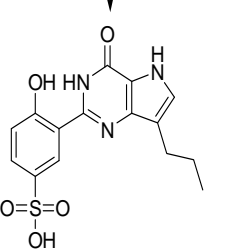

Exact Mass: 349.07

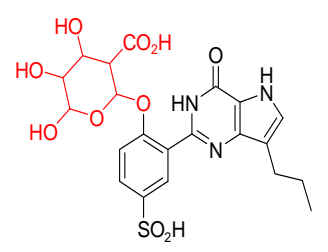

Exact Mass: 509.11

Figure 1: Metabolic pathways of mirodenafil and their chemical structures (4). 


\section{METHODS AND MATERIALS}

\section{Chemicals}

Mirodenafil, SK3541, and SK3544 were supplied from Life Science Research Center, SK Chemicals (Suwon, South Korea). Sildenafil [internal standard for the high-performance liquid chromatographic (HPLC) analysis of mirodenafil, SK3541, and SK3544], catalase, the reduced form of $\beta$ nicotinamide adenine dinucleotide phosphate (NADPH; as a tetrasodium salt), ethylendiamine tetraacetatic acid (EDTA; as a disodium salt), tri(hydroxymethyl)aminomethane (Tris)-buffer, and dextran (mol. wt. of 40-60 KDa) were purchased from Sigma-Aldrich Corporation (St. Louis, MO). The following non-specific inhibitor of CYP isozymes, main specific inhibitors and inducers of various CYP isozymes were also purchased from Sigma-Aldrich Corporation; SKF 525-A [SK; a non-specific inhibitor of CYP isoforms (8)], $\alpha$ naphthoflavone [NP; a main inhibitor of CYP1A subfamily (9)], furafylline [FF; a main inhibitor of CYP1A2 (10)], sulfaphenazole [SP; a main inhibitor of CYP2C6 (11)], cimetidine [CM; a main inhibitor of CYP2C11 (12)], quinine hydrochloride [QN; a main inhibitor of CYP2D subfamily (13)], diethyldithiocarbamate [DC; a main inhibitor of CYP2E1 (14)], and troleandomycin [TM; a main inhibitor of CYP3A1/2 (15)], 3-methylcholanthrene [MC; a main inducer of CYP1A1/2 (16)], orphenadrine citrate $[\mathrm{OP}$; a main inducer of CYP2B1/2 (17)], isoniazid [IN; a main inducer of CYP2E1 (18)], and dexamethasone phosphate [DX; a main inducer of CYP3A1/2 (19)]. Polyethylene glycol 400 (PEG 400) was a product from Showa Chemical Company (Tokyo, Japan). Other chemicals were of reagent or HPLC grade.

\section{Animals}

The protocols for these animal studies were approved by the Institute of Laboratory Animal Resources, Seoul National University, Seoul, South Korea. Male Sprague-Dawley rats (5-9 weeks old, weighing 220-300 g) were purchased from Samtako Bio Korea (Osan, South Korea). Rats were maintained in a clean-room (Animal Center for Pharmaceutical Research, College of Pharmacy, Seoul National University) at a temperature of between $23 \pm 2{ }^{\circ} \mathrm{C}$ with 12 -h light (0700-1900) and dark (1900-0700) cycles, and a relative humidity of $55 \pm 10 \%$. Rats were housed in metabolic cages (Tecniplast, Varese, Italy) under filtered pathogen- free air, and with food (Sam Yang Company, Pyeongtaek, South Korea) and water available ad libitum.

\section{Pretreatments of Rats with Various CYP Inducers and Inhibitors}

Rats received a single intravenous injection (via the jugular vein) of $80 \mathrm{mg}(2 \mathrm{~mL}) / \mathrm{kg}$ of sulfaphenazole (11) in SPT group, a single intraperitoneal injection of $50 \mathrm{mg}(3.3 \mathrm{~mL}) / \mathrm{kg}$ of SKF 525-A (8) in SKT group, $500 \mathrm{mg}(5 \mathrm{~mL}) / \mathrm{kg}$ of troleandomycin (15) in TMT group, or $20 \mathrm{mg}(5 \mathrm{~mL}) / \mathrm{kg}$ of quinine hydrochloride (13) in QNT rats, three daily intraperitoneal injections of $50 \mathrm{mg}(5 \mathrm{~mL}) / \mathrm{kg}$ of dexamethasone phosphate (19) in DXT group, 150 $\mathrm{mg}(3 \mathrm{~mL}) / \mathrm{kg}$ of isoniazid (18) in INT group, or 60 $\mathrm{mg}(5 \mathrm{~mL}) / \mathrm{kg}$ of orphenadrine citrate (17) in OPT group, or four daily intraperitoneal injections of 20 $\mathrm{mg}(3.3 \mathrm{~mL}) / \mathrm{kg}$ of 3 -methylcholanthrene (16) in MCT group. Control groups received an intraperitoneal (or intravenous) injection of 5 $\mathrm{mL} / \mathrm{kg}$ of $0.9 \% \mathrm{NaCl}$-injectable solution for SKC, TMC, QNC, DXC, INC, and OPC groups, or 3.3 $\mathrm{mL} / \mathrm{kg}$ of corn oil for MCC group. ' $\mathrm{T}$ ' and ' $\mathrm{C}$ ' refer to rats with pretreatment and control, respectively. During the pretreatment, the rats had free access to food and water.

\section{Intravenous Administration of Mirodenafil in Rats Pretreated with Various CYP Inducers and Inhibitors}

The procedures used for treatment of rats including the cannulation (early in the morning) of the carotid artery (for blood sampling) and the jugular vein (for drug administration) were similar to a reported method (20). Each rat was housed individually in a rat metabolic cage (Daejong Scientific Company, Seoul, South Korea) and allowed to recover from light ether anesthesia for $4-5 \mathrm{~h}$ before beginning the experiment. Each rat was not restrained in the present study. An experiment was performed just after injection for SPT and SPC groups, after $1 \mathrm{~h}$ for SKT, SKC, QNT, and QNC groups, after $2 \mathrm{~h}$ for TMT and TMC groups, on the forth day for DXT, DXC, INT, INC, OPT, and OPC groups, or on the fifth day for MCT and MCC groups (20).

Mirodenafil [dissolved in PEG 400 : distilled water $(1: 1, \mathrm{v} / \mathrm{v})]$ at a dose of $20 \mathrm{mg}(2 \mathrm{~mL}) / \mathrm{kg}$ was manually administered intravenously for $1 \mathrm{~min}$ via the jugular vein of control groups $(\mathrm{n}=10$ for $\mathrm{DXC}$ and INC groups, $\mathrm{n}=7$ for OPC, SKC, SPC, QNC, and TMC groups, and $\mathrm{n}=6$ for MCC group), and 
pretreated groups $(\mathrm{n}=8$ for DXT and MCT groups, $\mathrm{n}=7$ for INT, OPT, and TMT groups, and $\mathrm{n}=6$ for SPT, SKT, and QNT groups). Blood samples (approximately $0.12 \mathrm{~mL}$, each) were collected via the carotid artery at 0 (control), 1 (end of the administration), 5, 15, 30, 60, 90, 120, 180, 240, and $360 \mathrm{~min}$ after the start of the intravenous administration of mirodenafil. The procedures used for preparation and handling of the 24-h urine sample (Ae0-24h) were similar to a reported method (20).

\section{Disappearance of SK3541 after Incubation of SK3541 with Rat Hepatic Microsomes}

To investigate whether SK3541 is further metabolized via CYP isoforms in rat hepatic microsomes, the disappearance of SK3541 was measured. The procedures used for preparation of hepatic microsomes were similar to a reported method (21). The livers from five control rats were used. Protein content in hepatic microsomes was measured using a reported method (22). The disappearance (primarily metabolism) of SK3541 was determined after incubating the hepatic microsomes (equivalent to $0.5 \mathrm{mg}$ protein), $5-\mu \mathrm{L}$ of PEG 400 : distilled water $=1: 1(\mathrm{v} / \mathrm{v})$ containing final SK3541 concentrations of $0.5,1$, and $5 \mu \mathrm{g} / \mathrm{mL}$, and $50-\mu \mathrm{L}$ of $0.1 \mathrm{M}$ phosphate buffer of $\mathrm{pH} 7.4$ containing $1 \mathrm{mM}$ NADPH. The volume was adjusted to $0.5 \mathrm{~mL}$ by adding $0.1 \mathrm{M}$ phosphate buffer of $\mathrm{pH} 7.4$ in a water-bath shaker $\left[37^{\circ} \mathrm{C}, 500\right.$ oscillations/min (opm)]. The reaction was terminated by addition of $1 \mathrm{~mL}$ of acetonitrile after 20-min incubation.

Measurement of Hepatic $V_{\max }, K_{m}$ and $C L_{\text {int }}$ for the Disappearance of SK3541 with and without CYP Inhibitors

To investigate which hepatic CYP isoforms are responsible for the metabolism of SK3541 in rats, the disappearance of SK3541 was measured using the similar methods as mentioned above disappearance of SK3541 (21).

Maximum velocity $\left(V_{\max }\right)$ and the apparent Michaelis-Menten constant $\left(K_{\mathrm{m}}\right.$; the concentration at which the rate is one half of the $V_{\max }$ ) for the disappearance of SK3541 were determined after incubating the above microsomal fractions (equivalent to $0.5 \mathrm{mg}$ ), $5-\mu \mathrm{L}$ of methanol containing SK3541 final concentrations of $0.5,1,5,10,50$, 100,200 , and $500 \mu \mathrm{M}$ without and with $5-\mu \mathrm{L}$ of methanol containing a final concentration of $10 \mu \mathrm{M}$ $\alpha$-naptoprofen (9), $20 \mu \mathrm{M}$ furafylline (10), $50 \mu \mathrm{M}$ cimetidine (11), $10 \mu \mathrm{M}$ sulfaphenazole (12), $3 \mu \mathrm{M}$ quinine hydrochloride (12), $50 \quad \mu \mathrm{M}$ diethyldithiocarbamate (14), or $50 \quad \mu \mathrm{M}$ troleandomycin (12) and $50-\mu \mathrm{L}$ of $0.1 \mathrm{M}$ phosphate buffer of $\mathrm{pH} 7.4$ containing $1 \mathrm{mM}$ NADPH. The volume was adjusted to $0.5 \mathrm{ml}$ by adding $0.1 \mathrm{M}$ phosphate buffer ( $\mathrm{pH}$ 7.4). The components were incubated in a water-bath $\left(37{ }^{\circ} \mathrm{C}, 500 \mathrm{opm}\right)$. For the studies on the mechanism-based inhibitor $\quad(\alpha-$ naphthoflavone, furafylline, diethyldithiocarbamate, and troleandomycin) and controls, the microsomes, CYP inhibitor, and NADPH were preincubated for $15 \mathrm{~min}$ and 20 units of catalase were added to prevent auto-inactivation of CYP isozymes during preincubation of microsomes with NADPH (9). All of the microsomal incubation conditions were within the linear range of the reaction rate. The reaction was terminated by addition of $0.2 \mathrm{~mL}$ of acetonitrile to a $0.1 \mathrm{~mL}$ of sample after $20-\mathrm{min}$ incubation. Similar experiments were also performed in OPT and OPC rats $(n=5$, each) to investigate whether hepatic CYP2B1/2 is responsible for the metabolism of SK3541 in rats.

The kinetic constants $\left(K_{\mathrm{m}}\right.$ and $\left.V_{\max }\right)$ for the disappearance of SK3541 were calculated using a non-linear regression method (23) using Michaelis-Menten equation. The intrinsic clearance $\left(\mathrm{CL}_{\text {int }}\right)$ for the disappearance of SK3541 was calculated by dividing the $V_{\max }$ by the $K_{\mathrm{m}}$.

\section{Measurement of Rat Plasma Protein Binding of Mirodenafil Using Equilibrium Dialysis}

Protein binding values of mirodenafil to fresh plasma from OPT, DXT, SKT, and QNT rats and control rats were measured using equilibrium dialysis (24) at a mirodenafil concentration of 5 $\mu \mathrm{g} / \mathrm{mL}$. One milliliter of plasma was dialyzed against $1 \mathrm{~mL}$ of isotonic Sørensen phosphate buffer of $\mathrm{pH} 7.4$ containing 3\% (w/v) dextran ('the buffer') in a $1 \mathrm{~mL}$ dialysis cell (Spectrum Medical Industries, Los Angeles, CA) using a Spectra/Por 4 membrane (mol. wt. cutoff of 12-14 KDa; Spectrum Medical Industries). After 12-h incubation, two $100-\mu \mathrm{L}$ were removed from 'the buffer' and plasma compartments, respectively, and stored at $-70{ }^{\circ} \mathrm{C}$ until used for the HPLC analysis of mirodenafil.

HPLC Analysis of mirodenafil, SK3541, and SK3544

Concentrations of mirodenafil, SK3541, and 
SK3544 in the samples were determinated using a reported HPLC method (25). In brief, $75-\mu \mathrm{L}$ of acetonitrile containing $1 \mu \mathrm{g} / \mathrm{mL}$ sildenafil (internal standard) was added to $50-\mu \mathrm{L}$ of a sample. After vortex-mixing for $1 \mathrm{~min}$ and centrifugation (15000 $\times g, 10 \mathrm{~min}), 50-\mu \mathrm{L}$ of the supernatant was injected directly onto a reversed-phase $\left(\mathrm{C}_{18}\right.$; Symmetry ${ }^{\mathbb{R}}$; $100 \mathrm{~mm}, \ell . \times 4.6 \mathrm{~mm}$. i.d.; particle size, $3.5 \mu \mathrm{m}$; Waters, Milford, MA) HPLC column. The mobile phase, $20 \mathrm{mM}$ ammonium acetate : acetonitrile $(52: 48, \mathrm{v} / \mathrm{v})$, was run at a flow-rate of $1.4 \mathrm{~mL} / \mathrm{min}$, and the column eluent was monitored using an ultraviolet detector at $254 \mathrm{~nm}$, at room temperature. The retention times of SK3544, sildenafil (internal standard), SK3541, and mirodenafil were approximately 4.0, 5.6, 7.0, and $8.3 \mathrm{~min}$, respectively. The detection limits of mirodenafil and SK3541 in rat plasma and urine samples were all $0.03 \mu \mathrm{g} / \mathrm{mL}$. The corresponding values of SK3544 in rat plasma and urine samples were all $0.1 \mu \mathrm{g} / \mathrm{mL}$. The coefficients of variation (intra- and inter-day) were all below $9.83 \%$.

\section{Pharmacokinetic Analysis}

The total area under the plasma concentration-time curve from time zero to infinity (AUC) was calculated using the trapezoidal rule-extrapolation method (26). The area from the last datum point to time infinity was estimated by dividing the last measured plasma concentration by the terminalphase rate constant.

Standard methods (27) were used to calculate the following pharmacokinetic parameters using a non-compartment analysis (WinNonlin ${ }^{\circledR}$; professional edition version 2.1; Pharsight, Mountain View, CA); the time-averaged total body, renal, and non-renal clearances $\left(\mathrm{CL}, \mathrm{CL}_{\mathrm{R}}\right.$, and $\mathrm{CL}_{\mathrm{NR}}$, respectively), the terminal half-life, the mean residence time (MRT), and the apparent volume of distribution at steady state $\left(\mathrm{Vd}_{\mathrm{ss}}\right)$. The peak plasma concentration $\left(C_{\max }\right)$ and time to reach $C_{\max }\left(T_{\max }\right)$ were directly read from the experimental data.

\section{Statistical Analysis}

A $p$ value $<0.05$ was deemed to be statistically significant using an unpaired $t$-test. All data are expressed as means \pm standard deviations except medians (ranges) for $T_{\max }$.

\section{RESULTS}

Pharmacokinetics of Mirodenafil, SK3541, and SK3544 after Intravenous Administration of Mirodenafil in Rats Pretreated with Various CYP Inducers

After intravenous administration of mirodenafil at a dose of $20 \mathrm{mg} / \mathrm{kg}$ in MCT, OPT, INT, and DXT rats, and control rats $(\mathrm{MCC}, \mathrm{OPC}, \mathrm{INC}$, and DXC rats, respectively), the mean arterial plasma concentration-time profiles of mirodenafil and SK3541 are shown in Figure 2. The relevant pharmacokinetic parameters including SK3544 are listed in Table 1. After intravenous administration of mirodenafil, the mean arterial plasma concentrations of both mirodenafil and SK3541 declined in a poly-exponential fashion for all groups of rats. SK3544 was below the detection limit in all the plasma samples collected.

The AUCs of mirodenafil were significantly smaller in MCT, OPT, and DXT rats (by 28.7, 35.4, and $40.0 \%$, respectively) than controls. The corresponding values of CL (by 40.6, 58.0, and $63.9 \%$, respectively) and $\mathrm{CL}_{\mathrm{NR}}$ (by $39.4,59.3$, and $63.9 \%$, respectively) of mirodenafil were significantly faster than controls. In OPT and DXT rats, the $\mathrm{Vd}_{\mathrm{ss}} \mathrm{s}$ of mirodenafil were significantly larger (by 78.5\%) and smaller (by 53.9\%), respectively, than controls. In DXT rats, the terminal half-life, MRT, and $\mathrm{Ae}_{0-24} \mathrm{~h}$ were significantly shorter (by $61.6 \%$ ), shorter (by $72.2 \%$ ), and smaller (by $64.1 \%$ ) than controls. The AUCs of SK3541 were significantly smaller in MCC, OPT, and DXT rats (by 44.9, 34.2, and 60.1\%, respectively) than controls. In DXT rats, the terminal half-life of SK3541 was significantly shorter (by 49.7\%) than controls. Note that compared with DXC rats, the final body weight gain was significantly lighter (by $8.99 \%$ ) in DXT rats as reported in other studies (18). The $\mathrm{Ae}_{0-24 \mathrm{~h}}$ and $\mathrm{CL}_{\mathrm{R}}$ of mirodenafil after its intravenous administration to rats pretreated with all CYP inducers studied were almost negligible. Thus, the contribution of changes in the above two parameters to other pharmacokinetic parameters of mirodenafil could be almost negligible.

Pharmacokinetics of Mirodenafil, SK3541, and SK3544 after Intravenous Administration of Mirodenafil in Rats Pretreated with Various CYP Inhibitors

After intravenous administration of mirodenafil at a 
dose of $20 \mathrm{mg} / \mathrm{kg}$ in SKT, QNT, TMT, SPT rats and control rats (SKC, QNC, TMC, and SPC rats, respectively), the mean arterial plasma concentration-time profiles of mirodenafil and SK3541 are shown in Figure 3. The relevant pharmacokinetic parameters including SK3544 are listed in Table 2. After intravenous administration of mirodenafil, the mean arterial plasma concentrations of both mirodenafil and SK3541 also declined in a poly-exponential fashion for all groups of rats. SK3544 was also below the detection limit in all the plasma samples collected.

The AUCs of mirodenafil were significantly greater in SKT, QNT, and TMT rats (by 62.3, 53.5, and $48.9 \%$, respectively) than controls. The corresponding values of CLs (by 39.0, 36.1, and $33.2 \%$, respectively) and $\mathrm{CL}_{\mathrm{NR}} \mathrm{S}$ (by $39.0,36.1$, and $33.2 \%$, respectively) of mirodenafil were significantly slower than controls. The $\mathrm{Vd}_{\mathrm{ss}} \mathrm{s}$ of mirodenafil in SKT, QNT, and TMT rats were significantly smaller (by 29.4\%), smaller (by $35.2 \%$ ), and larger (by $26.8 \%$ ), respectively, than controls. In TMT rats, the terminal half-life and MRT of mirodenafil were significantly larger (by 48.2 and $86.6 \%$, respectively) than controls. In SPT rats, the terminal half-life, $\mathrm{CL}_{\mathrm{R}}$, and $\mathrm{Ae}_{0-24 \mathrm{~h}}$ were significantly larger (by $48.2 \%$ ), slower (by $57.7 \%$ ), and smaller (by 52.5\%), respectively, than controls. The AUCs of SK3541 in SKT, QNT, and TMT rats were significantly greater (by $38.6,68.5$, and $67.4 \%$, respectively) than controls. In TMT rats, the terminal half-life and $C_{\max }$ of SK3541 were significantly larger (by 16.4\%) and higher (by $66.6 \%$ ), respectively, than controls.

\section{Disappearance of SK3541 after Incubation of SK3541 with Rat Hepatic Microsomes}

In rat hepatic microsomal studies, the percentages of the spiked amount of SK3541 disappeared after 20-min incubation were $91.9,75.4$, and $49.5 \%$ for $0.5,1$, and $5 \mu \mathrm{g} / \mathrm{mL}$ of SK3541, respectively.

\section{Hepatic $V_{\max }, K_{m}$ and $C L_{\text {int }}$ for the Disappearance of SK3541 with and without CYP Inhibitors and CYP2B1/2 Inducer}

The $V_{\max }, K_{\mathrm{m}}$ and $\mathrm{CL}_{\mathrm{int}}$ for the disappearance (primarily metabolism) of SK3541 in hepatic microsomes are listed in Table 3. Among CYP inhibitors studied, the $V_{\max }$ was significantly slower only in TMT rats (by $74.8 \%$ ) than controls, suggesting that the maximum velocity for the disappearance of SK3541 was slower by troleandomycin. However, the $K_{\mathrm{m}} \mathrm{s}$ in FFT and QNT rats were significantly higher (by 47.3 and $119 \%$, respectively) than controls, suggesting that the affinity of enzymes for SK3541 decreased by furafylline and quinine. As a results, the $\mathrm{CL}_{\text {int }}$ sere significantly slower in FFT, QNT, and TMT rats (by $18.5,35.4$, and $51.5 \%$, respectively) than controls, suggesting that the disappearance of SK3541 was slower by furafylline, quinine, and troleandomycin. The above data suggest that inhibition of metabolism of SK3541 by troleandomycin was a non-competitive manner and that by furafylline and quinine was a competitive manner. In OPT rats, the $V_{\max }$ and $\mathrm{CL}_{\text {int }}$ were significantly faster (by 96.4 and $55.4 \%$, respectively) than controls.

\section{Rat Plasma Protein Binding of Mirodenafil Using Equilibrium Dialysis}

Protein binding values of mirodenafil to fresh plasma from MCT, OPT, INT, DXT, SKT, QNT, TMT, and SPT rats and control rats were $89.0 \pm$ $0.727,86.6 \pm 1.46,87.4 \pm 11.2,94.2 \pm 3.31,90.6 \pm$ $1.82,95.0 \pm 1.91,84.8 \pm 3.35,91.6 \pm 2.86$, and 87.8 $\pm 0.497 \%$, respectively. Compared with controls, the free (unbound to plasma proteins) fraction of mirodenafil was significantly greater in OPT and TMT rats (by 9.84 and $24.6 \%$, respectively), but significantly smaller in DXT, SKT, and QNT rats (by $52.5,23.0$, and $59.0 \%$, respectively).

It has been reported that binding of mirodenafil to $4 \%$ human serum albumin, similar to the ratio of albumin in rat plasma (28), was constant, $92.5 \%$, at mirodenafil concentrations from 0.5 to $100 \mu \mathrm{g} / \mathrm{mL}$ (24). Thus, a mirodenafil concentration of $5 \mu \mathrm{g} / \mathrm{mL}$ was used in this plasma protein binding studies.

\section{DISCUSSION}

In the present in vitro and in vivo studies, it was proven that metabolism of both mirodenafil and SK3541 was mediated via hepatic CYP1A1/2, $2 \mathrm{~B} 1 / 2$, 2D subfamily, and $3 \mathrm{~A} 1 / 2$ in rats. After intravenous administration of mirodenafil at doses of 5,10 , and $20 \mathrm{mg} / \mathrm{kg}$ in male Sprague-Dawley rats, the AUCs of both mirodenafil and SK3541 were dose-proportional (24). Thus, a $20 \mathrm{mg} / \mathrm{kg}$ intravenous dose of mirodenafil was chosen for this study.

After intravenous administration of mirodenafil in rats, the contribution of the $C_{R}$ to the $C L$ of mirodenafil was almost negligible (Tables 1 and 2). 
A

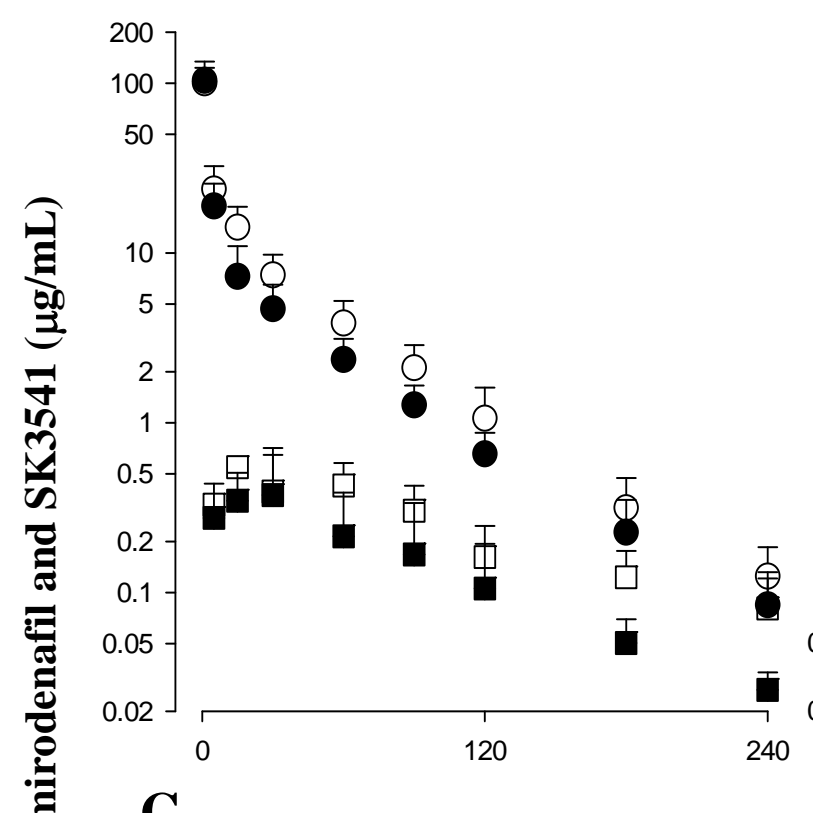

B

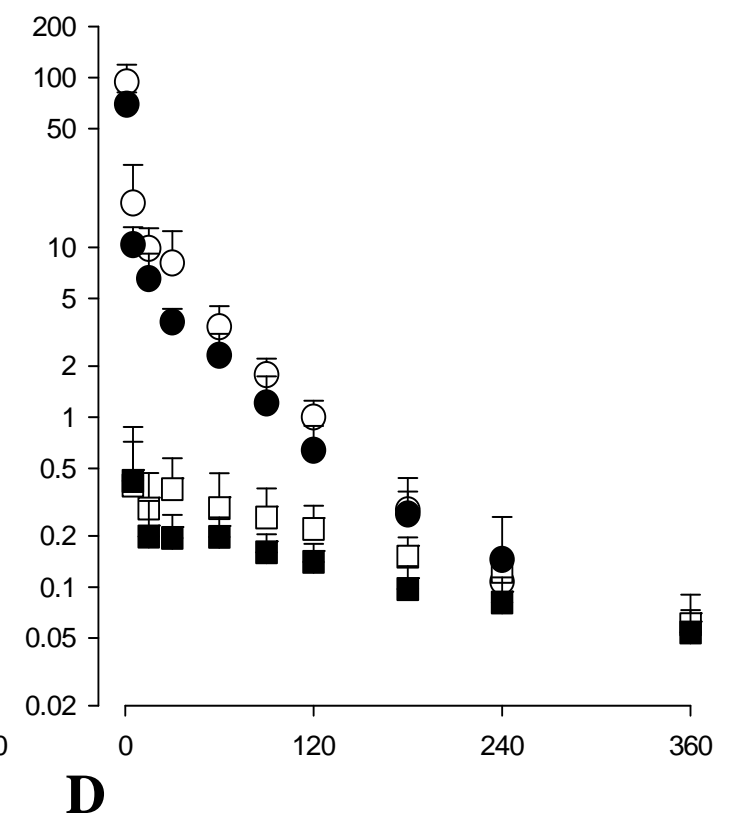

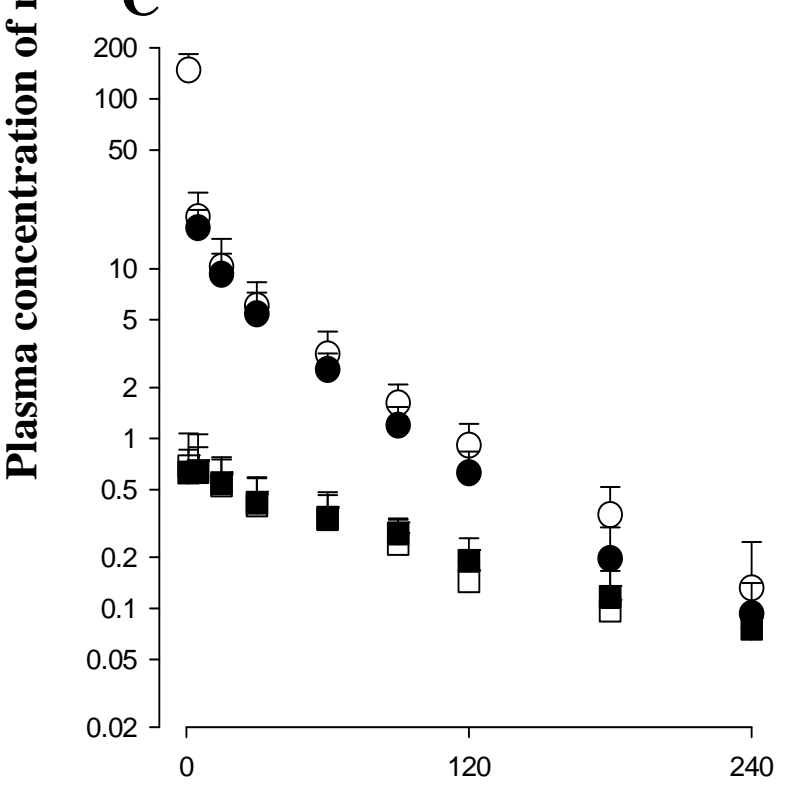

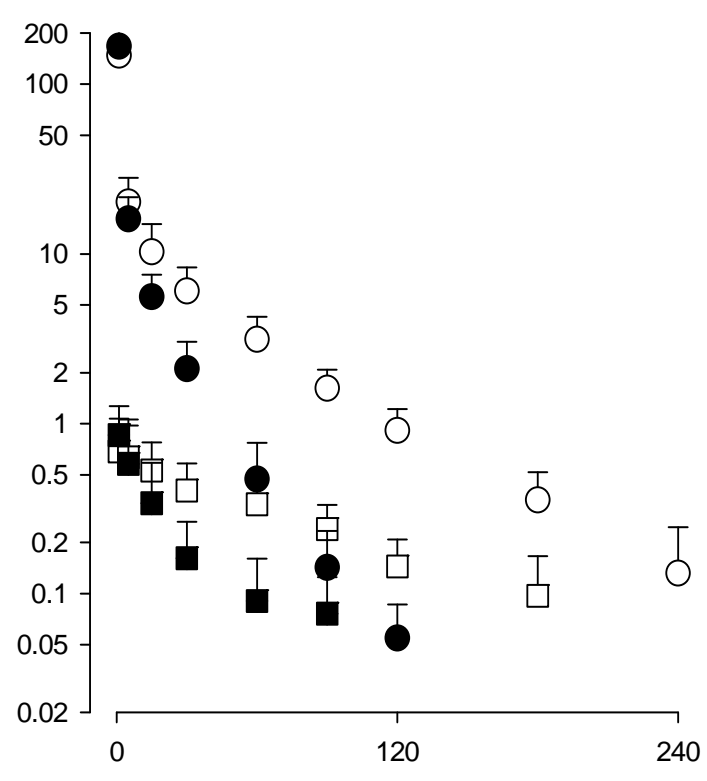

Time (min)

Figure 2. Mean arterial plasma concentration-time profiles of mirodenafil (circle) and SK3541 (square) after intravenous administration of mirodenafil at a dose of $20 \mathrm{mg} / \mathrm{kg}$ in rats pretreated with enzyme inducers (closed symbol), MC (MCT; A), OP (OPT; B), IN (INT; C), and DX (DXT; D), and control rats (MCC, OPC, INC, and DXC; open symbol). The number of rats are as followings; (A) $n=6$ for MCC rats and $n=8$ for MCT rats, (B) $n=7$ for both OPC and OPT rats, $(C) n=10$ for INC rats and $n=7$ for INT rats, and (D) $n=10$ for DXC rats and $n=8$ for DXT rats. Bars represent standard deviations. 
J Pharm Pharmaceut Sci (www.cspsCanada.org) 13(1) 93 - 106, 2010

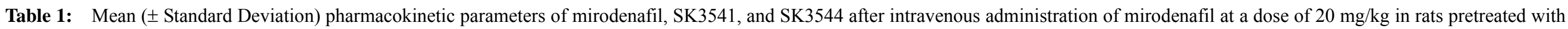
MC (MCT), OP (OPT), IN (INT), and DX (DXT), and respective control rats (MCC, OPC, INC, and DXC, respectively).

\begin{tabular}{|c|c|c|c|c|c|c|c|c|c|c|c|c|c|c|}
\hline \multirow{2}{*}{$\begin{array}{l}\text { Parameter } \\
\text { Initial body weight }(\mathrm{g})\end{array}$} & \multicolumn{2}{|c|}{$\operatorname{MCC}(n=6)$} & \multicolumn{2}{|c|}{$\operatorname{MCT}(n=8)$} & \multicolumn{2}{|c|}{ OPC $(n=7)$} & \multicolumn{2}{|c|}{ OPT $(n=7)$} & \multicolumn{2}{|c|}{ INC, DXC $(n=10)$} & \multicolumn{2}{|c|}{ INT $(n=7)$} & \multicolumn{2}{|c|}{ DXT $(n=8)$} \\
\hline & 246 & \pm 6.65 & 246 & \pm 4.43 & 247 & \pm 9.06 & 243 & \pm 3.93 & 275 & \pm 11.4 & 273 & \pm 15.1 & 269 & \pm 14.3 \\
\hline Final body weight (g) & 284 & \pm 8.01 & 278 & \pm 5.30 & 285 & \pm 10.0 & 279 & \pm 7.48 & 287 & \pm 26.5 & 278 & \pm 11.1 & 253 & $\pm 6.55^{\mathrm{b}}$ \\
\hline \multicolumn{15}{|l|}{ Mirodenafil } \\
\hline $\mathrm{AUC}(\mu \mathrm{g} \min / \mathrm{mL})$ & 951 & \pm 195 & 678 & $\pm 142^{\mathrm{a}}$ & 814 & \pm 110 & 526 & $\pm 114^{\mathrm{c}}$ & 894 & \pm 267 & 880 & \pm 108 & 536 & $\pm 132^{b}$ \\
\hline Terminal half-life (min) & 52.0 & \pm 11.3 & 43.4 & \pm 13.6 & 41.9 & \pm 6.42 & 48.6 & \pm 20.2 & 48.4 & \pm 16.2 & 50.4 & \pm 22.0 & 18.6 & $\pm 5.12^{\mathrm{b}}$ \\
\hline $\operatorname{MRT}(\min )$ & 35.5 & \pm 6.21 & 31.8 & \pm 8.33 & 37.3 & \pm 5.46 & 42.1 & \pm 14.6 & 34.8 & \pm 10.3 & 26.5 & \pm 10.2 & 9.66 & $\pm 4.64^{\mathrm{c}}$ \\
\hline $\mathrm{Vd}_{\mathrm{ss}}(\mathrm{mL} / \mathrm{kg})$ & 762 & \pm 154 & 965 & \pm 285 & 919 & \pm 185 & 1640 & $\pm 582^{\mathrm{b}}$ & 738 & \pm 185 & 621 & \pm 294 & 340 & $\pm 130^{\mathrm{c}}$ \\
\hline $\mathrm{CL}(\mathrm{mL} / \mathrm{min} / \mathrm{kg})$ & 21.7 & \pm 3.95 & 30.5 & $\pm 5.36^{\mathrm{c}}$ & 25.0 & \pm 3.44 & 39.5 & $\pm 8.94^{\mathrm{b}}$ & 24.1 & \pm 6.58 & 23.0 & \pm 2.99 & 39.5 & $\pm 10.8^{\mathrm{b}}$ \\
\hline $\mathrm{CL}_{\mathrm{R}}(\mathrm{mL} / \mathrm{min} / \mathrm{kg})$ & 0.0700 & \pm 0.0995 & 0.0580 & \pm 0.0239 & 0.114 & \pm 0.163 & 0.0697 & \pm 0.0195 & 0.0376 & \pm 0.0171 & 0.0389 & \pm 0.0111 & 0.0231 & \pm 0.0184 \\
\hline $\mathrm{CL}_{\mathrm{NR}}(\mathrm{mL} / \mathrm{min} / \mathrm{kg})$ & 21.6 & \pm 3.91 & 30.1 & $\pm 5.35^{\mathrm{c}}$ & 24.8 & \pm 3.45 & 39.5 & $\pm 8.94^{\mathrm{b}}$ & 24.1 & \pm 6.56 & 23.0 & \pm 2.99 & 39.5 & $\pm 10.8^{\mathrm{b}}$ \\
\hline $\begin{array}{l}\mathrm{Ae}_{0-24 \mathrm{~h}} \\
(\% \text { of mirodenafil dose) }\end{array}$ & 0.306 & \pm 0.405 & 0.193 & \pm 0.072 & 0.460 & \pm 0.675 & 0.180 & \pm 0.0536 & 0.151 & \pm 0.044 & 0.168 & \pm 0.179 & 0.0542 & $\pm 0.034^{\mathrm{b}}$ \\
\hline \multicolumn{15}{|l|}{ SK3541 } \\
\hline $\mathrm{AUC}(\mu \mathrm{g} \min / \mathrm{mL})$ & 63.7 & \pm 15.2 & 35.1 & $\pm 23.1^{\mathrm{a}}$ & 62.3 & 21.4 & 41.0 & $\pm 10.9^{\mathrm{a}}$ & 80.0 & \pm 32.3 & 87.7 & \pm 32.5 & 31.9 & $\pm 17.3^{\mathrm{b}}$ \\
\hline Terminal half-life (min) & 89.4 & \pm 21.7 & 73.9 & \pm 21.5 & 62.0 & 9.39 & 67.1 & \pm 18.5 & 77.9 & \pm 29.8 & 78.7 & \pm 29.6 & 39.2 & $\pm 11.9^{\mathrm{b}}$ \\
\hline$C_{\max }(\mu \mathrm{g} / \mathrm{mL})$ & 0.534 & \pm 0.168 & 0.445 & \pm 0.312 & 0.483 & \pm 0.250 & 0.341 & \pm 0.263 & 0.751 & \pm 0.428 & 0.726 & \pm 0.170 & 0.868 & \pm 0.396 \\
\hline$T_{\max }(\min )^{\mathrm{d}}$ & \multicolumn{2}{|c|}{$15(15-30)$} & \multicolumn{2}{|c|}{$15(15-30)$} & \multicolumn{2}{|c|}{$30(5-60)$} & \multicolumn{2}{|c|}{$30(15-60)$} & \multicolumn{2}{|c|}{$5(5-30)$} & \multicolumn{2}{|c|}{$15(5-60)$} & \multicolumn{2}{|c|}{$5(5-30)$} \\
\hline $\mathrm{CL}_{\mathrm{R}}(\mathrm{mL} / \mathrm{min} / \mathrm{kg})$ & 0.0289 & \pm 0.0330 & 0.0505 & \pm 0.0425 & 0.178 & \pm 0.386 & 0.0281 & \pm 0.0157 & 0.00550 & \pm 0.00484 & 0.00974 & \pm 0.00414 & 0.00937 & \pm 0.00843 \\
\hline $\begin{array}{l}\mathrm{Ae}_{0-24 \mathrm{~h}} \\
(\% \text { of mirodenafil dose) }\end{array}$ & 0.0119 & \pm 0.0164 & 0.00693 & \pm 0.00433 & 0.0793 & \pm 0.187 & 0.00588 & \pm 0.00273 & 0.00209 & \pm 0.00183 & 0.00930 & \pm 0.0134 & 0.00103 & \pm 0.00104 \\
\hline $\begin{array}{l}\mathrm{AUC}_{\mathrm{SK} 3541} / \mathrm{AUC}_{\text {mirodenafil }} \\
(\%)\end{array}$ & 6.87 & \pm 2.03 & 5.18 & \pm 3.37 & 7.55 & \pm 2.16 & 7.93 & \pm 1.93 & 8.85 & \pm 1.86 & 9.78 & \pm 1.64 & 6.23 & \pm 3.67 \\
\hline \multicolumn{15}{|l|}{ SK3544 } \\
\hline $\begin{array}{l}\mathrm{Ae}_{0-24 \mathrm{~h}} \\
(\% \text { of mirodenafil dose) }\end{array}$ & 0.285 & \pm 0.283 & 0.179 & \pm 0.0524 & 0.768 & \pm 0.836 & 0.190 & \pm 0.0685 & 0.359 & \pm 0.243 & 0.320 & \pm 0.179 & 0.244 & \pm 0.183 \\
\hline
\end{tabular}


J Pharm Pharmaceut Sci (www.cspsCanada.org) 13(1) 93 - 106, 2010

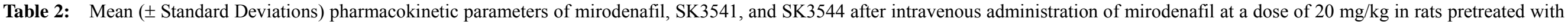
SK (SKT), QN (QNT), TM (TMT), and SP (SPT), and their respective control rats (SKC, QNC, TMC, SPC, respectively).

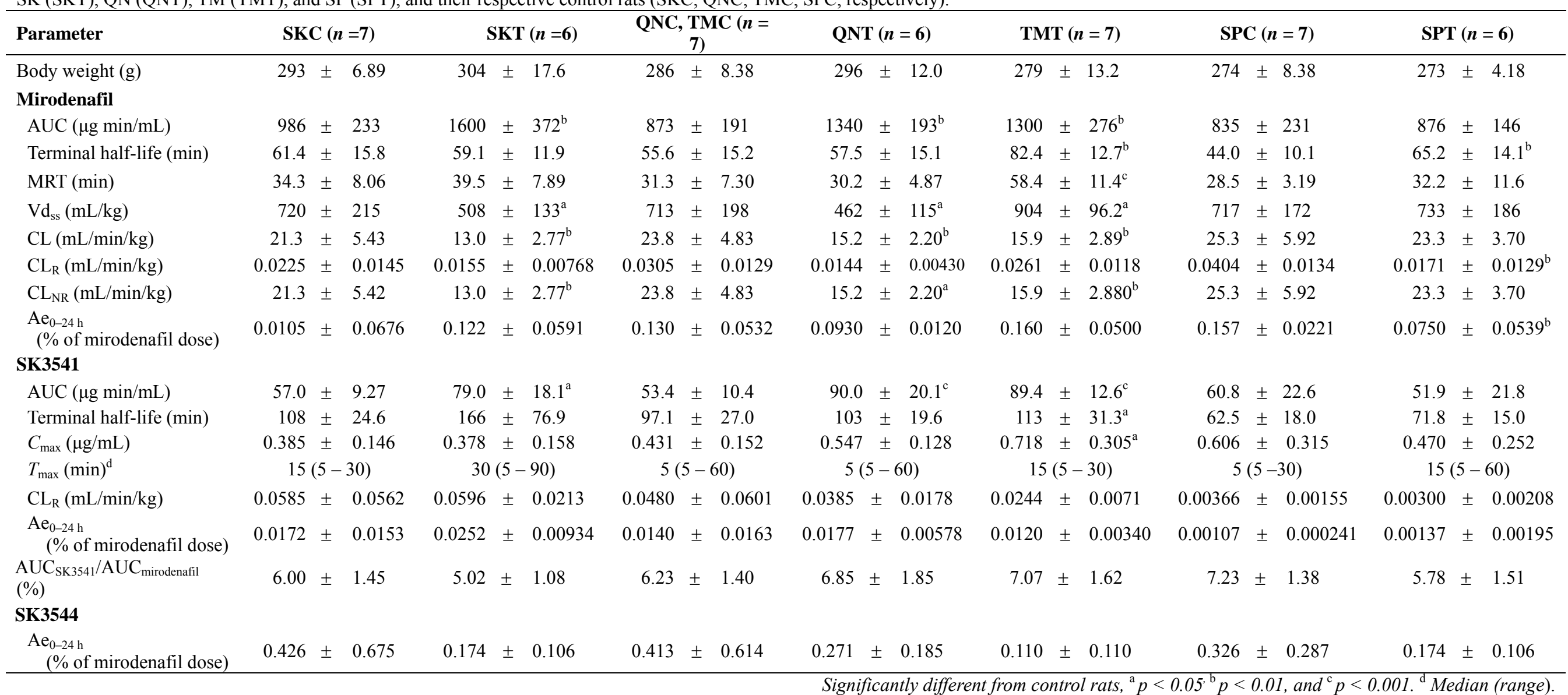


J Pharm Pharmaceut Sci (www.cspsCanada.org) 13(1) 93 - 106, 2010

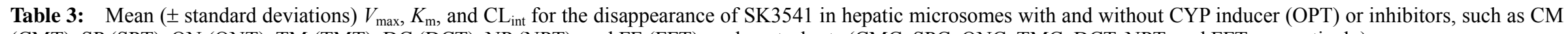
(CMT), SP (SPT), QN (QNT), TM (TMT), DC (DCT), NP (NPT), and FF (FFT), and control rats (CMC, SPC, QNC, TMC, DCT, NPT, and FFT, respectively).

\begin{tabular}{|c|c|c|c|c|c|}
\hline Parameter & $\begin{array}{c}\text { CMC, OPC, SPC, QNC } \\
(n=5)\end{array}$ & $\begin{array}{c}\text { OPT } \\
(n=5)\end{array}$ & $\begin{array}{r}\text { CMT } \\
(n=5) \\
\end{array}$ & $\begin{array}{c}\text { SPT } \\
(n=5)\end{array}$ & $\begin{array}{l}\text { QNT } \\
(n=5)\end{array}$ \\
\hline$V_{\max }(\mathrm{nmoL} / \mathrm{min} / \mathrm{mg}$ protein $)$ & $6.67 \pm 2.44$ & $13.1 \pm 3.74^{\mathrm{a}}$ & $4.99 \pm 1.90$ & $4.90 \pm 1.61$ & $9.31 \pm 3.85$ \\
\hline$K_{\mathrm{m}}(\mu \mathrm{M})$ & $172 \pm 43.4$ & $224 \pm 44.3$ & $125 \pm 51.6$ & $130 \pm 34.1$ & $376 \pm 152^{\mathrm{a}}$ \\
\hline \multirow[t]{2}{*}{$\mathrm{CL}_{\text {int }}(\mathrm{mL} / \mathrm{min} / \mathrm{mg}$ protein $)$} & $0.0379 \pm 0.000625$ & $0.0589 \pm 0.00168^{\mathrm{a}}$ & $0.0419 \pm 0.0112$ & $0.0375 \pm 0.00551$ & $0.0245 \pm 0.00255^{\mathrm{a}}$ \\
\hline & $\begin{array}{c}\text { TMC, DCC, NPC, FFC } \\
(n=5)\end{array}$ & $\begin{array}{c}\text { TMT } \\
(n=5)\end{array}$ & $\begin{array}{c}\text { DCT } \\
(n=5)\end{array}$ & $\begin{array}{c}\text { NPT } \\
(n=4)\end{array}$ & $\begin{array}{c}\text { FFT } \\
(n=5)\end{array}$ \\
\hline$V_{\max }(\mathrm{nmoL} / \mathrm{min} / \mathrm{mg}$ protein $)$ & $5.87 \pm 1.27$ & $1.48 \pm 0.311^{\mathrm{c}}$ & $9.91 \pm 4.88$ & $7.37 \pm 1.32$ & $7.31 \pm 1.28$ \\
\hline$K_{\mathrm{m}}(\mu \mathrm{M})$ & $226 \pm 73.4$ & $169 \pm 147$ & $342 \pm 170$ & $334 \pm 102$ & $333 \pm 53.5^{\mathrm{a}}$ \\
\hline $\mathrm{CL}_{\text {int }}(\mathrm{mL} / \mathrm{min} / \mathrm{mg}$ protein $)$ & $0.0270 \pm 0.00438$ & $0.0131 \pm 0.00754^{\mathrm{b}}$ & $0.0295 \pm 0.00692$ & $0.0227 \pm 0.00296$ & $0.0220 \pm 0.00183^{\mathrm{a}}$ \\
\hline
\end{tabular}

This suggests that intravenous mirodenafil was almost completely eliminated via a non-renal route $\left(\mathrm{CL}_{\mathrm{NR}}\right)$. After intravenous administration of mirodenafil, the contribution of the gastrointestinal (including the biliary) excretion of unchanged drug to the $\mathrm{CL}_{\mathrm{NR}}$ of mirodenafil was almost negligible; the percentages of the intravenous dose of mirodenafil at doses of $5-20 \mathrm{mg} / \mathrm{kg}$ recovered from the gastrointestinal tract (including its contents and feces) at 24 $\mathrm{h}$ as unchanged drug $\left(\mathrm{GI}_{24} \mathrm{~h}\right)$ and the 24-h biliary excretion of mirodenafil were almost negligible (24). Also mirodenafil has been found to be stable in rats' gastric and bile juices (24). Thus, the $\mathrm{CL}_{\mathrm{NR}} \mathrm{S}$ of mirodenafil listed in Tables 1 and 2 could have represented its metabolic clearances, not likely due to the chemical and enzymatic degradation of mirodenafil in rats' gastrointestinal and bile juices. Additionally, changes in the $\mathrm{CL}_{\mathrm{NR}}$ of mirodenafil could have represented changes in its metabolism in rats.

To find whether hepatic CYP isoforms are involved in the metabolism of mirodenafil in rats, SKF 525-A (a non-specific inhibitor of hepatic CYP isoforms in rats) was administered in rats. Compared with SKC rats, the significantly slower $\mathrm{CL}_{\mathrm{NR}}$ of mirodenafil in SKT rats (Table 2) indicates that mirodenafil is metabolized via hepatic CYP isoforms in rats. Thus, various hepatic CYP inducers and inhibitors were administered to find what types of hepatic CYP isoforms are involved in the metabolism of mirodenafil in rats. Although the various main inhibitors (inducers) of each CYP isozyme used in this study were reported to be generally used as specific inhibitors (inducers) in in vivo metabolism studies, they might involved for the inhibitors (inducers) of minor other CYP isozymes. Thus, the present results are confined to the main CYP isoforms. In MCT, OPT, and DXT (main inducers of CYP1A1/2, 2B1/2, and $3 \mathrm{~A} 1 / 2$ in rats, respectively) rats, the $\mathrm{CL}_{\mathrm{NR}} \mathrm{S}$ of mirodenafil were significantly faster than controls (Table 1). In contrast, in QNT and TMT (main inhibitors of CYP2D subfamily and 3A1/2 in rats, respectively) rats, the $\mathrm{CL}_{\mathrm{NR}} \mathrm{S}$ of mirodenafil were significantly slower than controls (Table 2). 


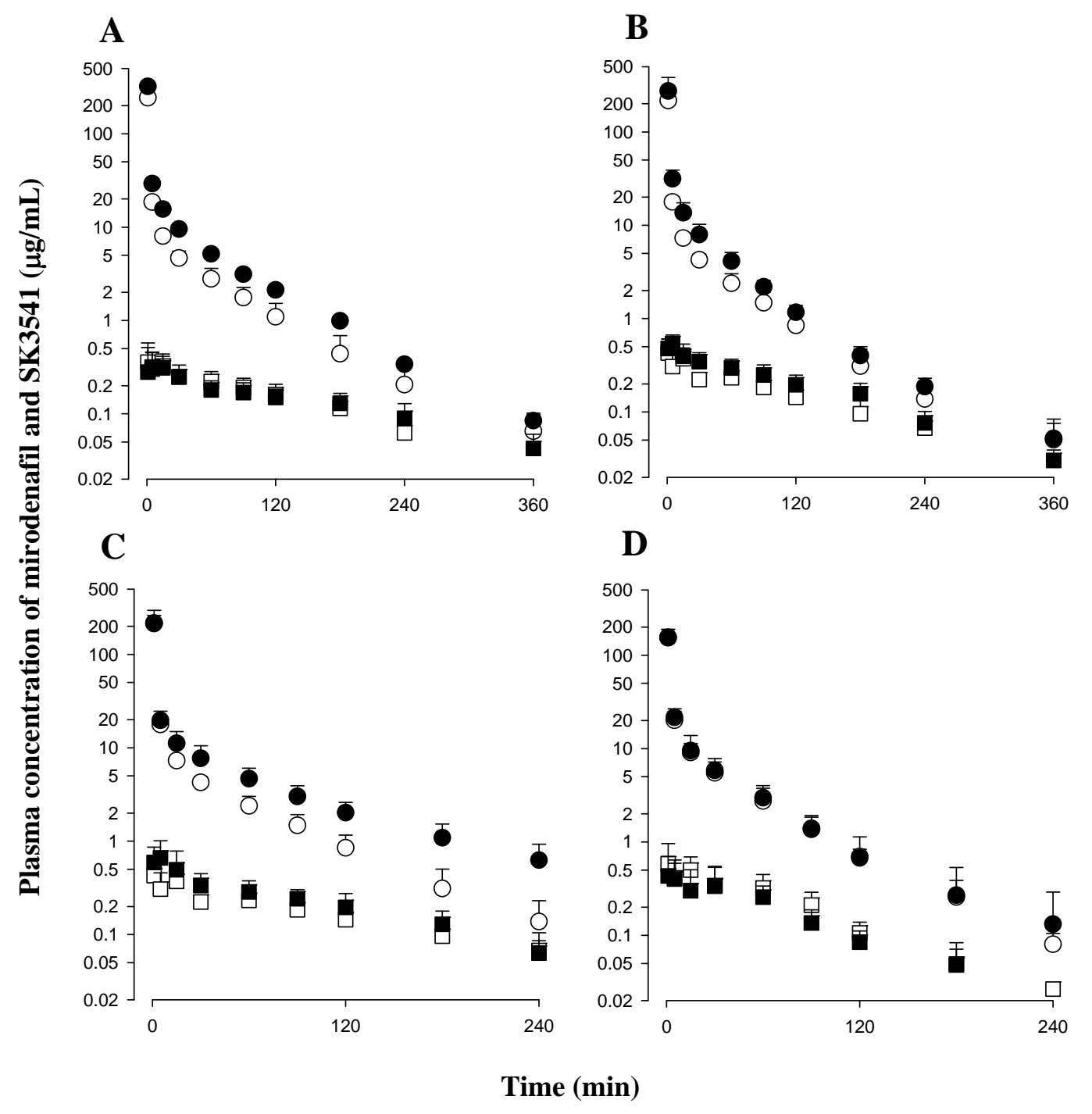

Figure 3: Mean arterial plasma concentration-time profiles of mirodenafil (circle) and SK3541 (square) after intravenous administration of mirodenafil at a dose of $20 \mathrm{mg} / \mathrm{kg}$ in rats pretreated with enzyme inhibitors (closed symbol), SK (SKT; A), QN (QNT; B), TM (TMT; C), and SP (SPT; D), and control rats (SKC, QNC, TMC, and SPC; open symbol). The number of rats are as followings; (A) $n=7$ for SKC rats and $n=6$ for SKT rats, (B) $n=7$ for QNC rats and $n=6$ for QNT rats, (C) $n=7$ for both TMC and TMT rats, and (D) $n=7$ for SPC rats and $n=6$ for SPT rats. Bars represent standard deviations.

The above data suggest that hepatic CYP1A1/2, 2B1/2, 2D subfamily, and $3 \mathrm{~A} 1 / 2$ could contribute to the metabolism of mirodenafil in rats.

Unexpectedly, the $\mathrm{AUC}_{\mathrm{SK} 3541} / \mathrm{AUC}_{\text {mirodenafil }}$ ratios with various CYP inducers (Table 1) and inhibitors (Table 2) were not significantly increased and decreased, respectively, than controls. This could have been due to that SK3541 was further metabolized via hepatic CYP1A2, 2B1/2, 2D subfamily, and $3 \mathrm{~A} 1 / 2$ in rats as mentioned in the hepatic microsomal studies (Table 3 ) and previous report (5). Moreover, the metabolites of SK3541 (Figure 1) were not measured in the present study. The above data suggest that in vivo CYP inducers 
and inhibitors are not appropriate for determination of CYP enzymes responsible for the metabolism of SK3541 after intravenous administration of mirodenafil. Thus, the in vitro studies for the measurement of $\mathrm{CL}_{\text {int }}$ for the disappearance of SK3541 were performed.

In vitro rat hepatic microsomal studies, the $\mathrm{CL}_{\mathrm{int}} \mathrm{S}$ for the disappearance of SK3541 by furafylline, quinine, and troleandomycin (main inhibitors of CYP1A1, 2D subfamily, 3A1/2, respectively) were significantly slower and that by orphenadrine (an inducer of CYP2B1/2) was significantly faster than that of respective controls. The above data (based on changes in the $\mathrm{CL}_{\text {int }}$ ) suggest that SK3541 was mainly metabolized via hepatic CYP1A2, 2B1/2, 2D subfamily, and 3A1/2 in rats. In vitro humans hepatic microsomal studies, CYP3A was the major enzyme and CYP2C8 was a minor enzyme for the metabolism of mirodenafil (5). In the present in vivo rat studies, hepatic CYP1A1/2, 2B1/2, 2D subfamily and 3A1/2 could contribute to the metabolism of mirodenafil. The homologies between human $\mathrm{CYP} 2 \mathrm{C} 8,3 \mathrm{~A} 3,3 \mathrm{~A} 4$, $3 \mathrm{~A} 5$, and $3 \mathrm{~A} 7$ and rat $\mathrm{CYP} 2 \mathrm{C} 13,3 \mathrm{~A} 1,3 \mathrm{~A} 1,3 \mathrm{~A} 2$, and $3 \mathrm{~A} 2$ are $68,78,73,71$, and $65 \%$, respectively (7).

Compared with controls, the $\mathrm{Vd}_{\mathrm{ss}}$ of mirodenafil was significantly larger in TMT rats, but was significantly smaller in DXT, SKT, and QNT rats (Tables 1 and 2). This could have mainly been due to a decrease in the free fractions of mirodenafil in the plasma from DXT, SKT, and QNT rats, and an increase from TMT rats. However, in OPT rats, the free fraction of mirodenafil increased by only $9.84 \%$, whereas the $\mathrm{Vd}_{\mathrm{ss}}$ increased by $78.5 \%$ compared with controls (Table 2 ). The exact reason for this is unclear and further studies are needed to determine the reason.

\section{CONCLUSIONS}

Metabolism of both mirodenafil and SK3541 was mediated via hepatic CYP1A1/2, 2B1/2, 2D subfamily, and $3 \mathrm{~A} 1 / 2$ in rats. The present results will play an important role in explaining the possible pharmacokinetic changes of mirodenafil and SK3541 in various rat disease models in which the CYP isoforms mentioned above are changed. For example, in rats with protein-calorie malnutrition (29), acute renal failure induced by uranyl nitrate (30), and diabetes mellitus induced by alloxan or streptozotocin (31), mutant Nagase analbuminemic rats, an animal model for human familial analbuminemia (32), and rats pretreated with lipopolysaccharide endotoxin induced by $E$. coli (33) or Klebsiella pneumoniae (34). These results could also contribute to explain possible drug-drug interactions between mirodenafil and other drugs which are primarily metabolized via hepatic CYP1A1/2, 2B1/2, 2D subfamily and/or $3 \mathrm{~A} 1 / 2$.

\section{ACKNOWLEDGMENT}

This study was supported in part by a contract, "Pharmacokinetics of mirodenafil" from SK Chemicals, Seoul, South Korea.

\section{Abbreviations:}

HPLC, high-performance liquid chromatography; AUC, total area under the plasma concentration-time curve from time zero to infinity; MRT, mean residence time; $\mathrm{Vd}_{\mathrm{ss}}$, apparent volume of distribution at steady state; CL, time-averaged total body clearance; $\mathrm{CL}_{\mathrm{R}}$, time-averaged renal clearance; $\mathrm{CL}_{\mathrm{NR}}$, time-averaged non-renal clearance; $K_{\mathrm{m}}$, apparent Michaelis-Menten constant; $V_{\max }$, maximum velocity; $\mathrm{CL}_{\text {int }}$, intrinsic clearance; $\mathrm{Ae}_{0-24} \mathrm{~h}$, percentage of the dose excreted in the 24-h urine; $C_{\max }$, peak plasma concentration; $T_{\max }$, time to reach $C_{\max }$.

\section{REFERENCES}

1. Yoo, H.-H., Kim, N.-S., Im, G.-J., Kim, D.-H., Pharmacokinetics and tissue distribution of a novel PDE5 inhibitor, SK-3530, in rats. Acta. Pharmacol. Sin. 28: 1247-1253, 2007.

2. Aversa, A., Bruzziches, R., Pili, M., Spera, G., Phosphodiesterase 5 inhibitors in the treatment of erectile dysfunction. Curr. Pharm. Res. 12: 3467-3484, 2006.

3. Broderick, G.A., Oral pharmacotherapy and the contemporary evaluation and management of erectile dysfunction. Rev. Urol. 5: S9-S20, 2003.

4. Lee, J., Yoo, H.H., Rhim, K.J., Sohn, D.-R., Kim, D.-H., Metabolism and excretion of 5ethyl-2-\{5-[4-(2-hydroxyethyl)piperazine-1sulfonyl]-2-pro-poxy-phenyl\}-7-propyl-3,5dihydropyrrolo[3,2-d]-pyrimidin-4-one

(SK3530) in rats. Rapid Commun. Mass Spectrum. 21: 1139-1149, 2007.

5. Lee, H.S., Park, E.J., Ji, H.Y., Kim, S.Y., Im, G.J., Lee, S.M., Jang, I.J., Identification of cytochrome P450 enzymes responsible for Ndealkylation of a new oral erectogenic, mirodenafil. Xenobiotica 38: 21-33, 2008.

6. Tingle, M.D., Helsby, N.A., Can in vitro drug metabolism studies with human tissue replace in vivo animal studies? Env. Toxicol. Pharmacol. 
21: 184-190, 2006.

7. Lewis, D.F.V., Cytochrome P450: Structure, Function, and Mechanism. Taylor \& Fancis, London, pp 122-123, 1996.

8. Conney, A.H., Environmental factors influencing drug metabolism. In: La Du, B.N., Mandel, H.G., Way, E.L. (eds). Fundamentals of drug metabolism and drug disposition. Williams \& Wilkins Company, Baltimore, p 269, 1971.

9. Huwkey, S.W., Dean, D.C., Miller, R.R., Rasmusson, G.H., Chiu, S.-H., Identification of human cytochrome $\mathrm{P} 450$ isozymes responsible for the in vitro oxidative metabolism of finasteride. Drug Metab. Dispos. 23: 1126-1135, 1995.

10. Clarke, S.E., Ayrton, A.D., Chenery, R.J., Characterization of the inhibition of P4501A2 by furafylline. Xenobiotica 24: 517-526, 1994.

11. Kobayashi, K., Urashima, K., Shimada, N., Chiba, K., Selectivities of human cytochrome P450 inhibitors toward rat P450 isoforms: study with cDNA-expressed systems of the rat. Drug Metab. Dispos. 31: 833-836, 2003.

12. Kobayashi, S., Murray, S., Watson, D., Sesardic, D., Davies, D.S., Boobis, A.R., The specificity of inhibition of debrisoquine 4-hydroxylase activity by quinidine and quinine in the rat is the inverse of that in man. Biochem. Pharmacol. 38: 2795-2799, 1989.

13. Tomkins, D.M., Otton, S.V., Joharchi, N., Li, N.-Y., Balster, R.F., Tyndale, R.F., Sellers, E.M., Effects of cytochrome P450 2D1 inhibition on hydrocodone metabolism and its behavioral consequences in rats. J. Pharmacol. Exp. Ther. 280: 1374-1382, 1997.

14. Spracklin, D.K., Hankins, D.C., Fisher, J.M., Thummel, K.E., Kharasch, E.D., Cytochrome P450 2E1 is the principal catalyst of human oxidative halothane metabolism in vitro. J. Pharmacol. Exp. Ther. 281: 400-411, 1997.

15. Sinclair, J.F., Szakacs, J.G., Wood, S.G., Kostrubsky, V.E., Jeffery, E.H., Wrighton, S.A., Bement, W.J., Wright, D., Sinclair, P.R., Acetaminophen hepatotoxicity precipitated by short-term treatment of rats with ethanol and isopentanol: protection by triacetyloleandomycin. Biochem. Pharmacol. 59: 445-454, 2000.

16. Williams, J.F., Lowitt, S., Szentivanyi, A., Effect of phenobarbital and 3methylcholanthrene pretreatment on the plasma half-life and urinary excretion profile of theophylline and its metabolites in rats. Biochem. Pharmacol. 28: 2935-2940, 1979.

17. Murray, M., Fiala-Beer, E., Sutton, D., Upregulation of cytochromes $\mathrm{P} 450$ 2B in rat liver by orphenadrine. Br. J. Pharmacol. 139: 787-796, 2003.

18. Ryan, D.E., Ramanathan, L., Iida, S., Thomas, P.E., Characterization of a major form of rat hepatic microsomal cytochrome P-450 induced by isoniazid. J. Biol. Chem. 260: 6385-6393, 1985.

19. Arlotto, M.P., Sonderfan, A.J., Klaassen, C.D., Pakinson, A., Studies on the pregnenolone-16 alpha-carbonitrile-inducible form of rat liver microsomal cytochrome P-450 and UDPglucuronosyl transferase. Biochem. Pharmacol. 36: 3859-3866, 1987.

20. Choi, Y.H. Lee, M.G., Effect of enzyme inducers and inhibitors on the pharmacokinetics of metformin in rats: involvement of CYP2C11, 2D1 and $3 \mathrm{~A} 1 / 2$ for the metabolism of metformin. Br. J. Pharmacol. 149: 424-430, 2006.

21. Choi, Y.H., Chung, S.J., Lee, M.G., Pharmacokinetic interaction between DA8159, a new erectogenic, and metformin in rats: competitive inhibition of metabolism via hepatic CYP3A1/2. Br. J. Pharmacol. 153: 1568-1578. 2008.

22. Bradford, M.M., A rapid and sensitive method for the quantitation of microgram quantities of protein utilizing the principle of protein-dye binding. Anal. Biochem. 72: 248-254, 1976.

23. Duggleby, R.G., Analysis of enzyme progress curves by nonlinear regression. Methods Enzymol. 249: 61-90, 1995.

24. Choi, Y.H., Lee, Y.S., Kim, T.K., Lee, B.-Y., Lee, M.G., Dose-dependent pharmacokinetics and first-pass effects of mirodenafil, a new erectogenic, in rats. Biopharm. Drug Dispos. 30: 305-317, 2009.

25. Choi, Y.H., Lee, Y.S., Kim, T.G., Im, G.-J., Lee, B.-Y., Lee, M.G., Simultaneous LC-UV analysis of mirodenafil and its two main metabolites in rat plasma and urine, and in tissue homogenates. Chromatographia 69: 677683, 2009.

26. Chiou, W.L., Critical evaluation of potential error in pharmacokinetic studies using the linear trapezoidal rule method for the calculation of the area under the plasma level-time curve. J. Pharmacokinet. Biopharm. 6: 539-546, 1978.

27. Gibaldi, M. and Perrier, D., Pharmacokinetics. 2nd ed. Marcel-Dekker, New York, NY, USA, 1982.

28. Mitruka, B.M., and Rawnsley, H.M., Clinical, Biochemical and Hematological Reference Values in Normal Experimental Animals and Normal humans, 2nd ed. Masson Publishing, New York, NY, USA, 1981.

29. Cho, M.K., Kim, Y.G., Lee, M.G., Kim. S.G., Suppression of rat hepatic cytochrome P450s by protein-calorie malnutrition: complete or partial restoration by cysteine or methionine supplementation. Arch. Biochem. Biophys. 372: 150-158, 1999.

30. Moon, Y.J., Lee, A.K., Chung, H.C., Kim, E.J., Kim, S.H., Lee, D.C., Lee, I., Kim, S.G., Lee, 
M.G., Effects of acute renal failure on the pharmacokinetics of chlorozoxazone in rats. Drug Metab. Dispos. 31: 776-784, 2003.

31. Kim, Y.C., Lee, A.K., Lee, J.H., Lee, I., Lee, D.C., Kim, S.H., Kim, S.G., Lee, M.G., Pharmacokinetics of theophylline in diabetes mellitus rats: induction of CYP1A2 and CYP2E1 on 1,3-dimethyluric acid formation. Eur. J. Pharm. Sci. 26: 114-123, 2005.

32. Kim, E.J., Lee, A.K., Kim, S.H., Kim, S.G., Lee, M.G., Pharmacokinetics and pharmacodynamics of intravenous azosemide in mutant Nagase analbuminemic rats. Drug Metab. Dispos. 31: 194-201, 2003.
33. Lee, J.H., Cho, Y.K., Jung, Y.S., Kim, Y.C., Lee, M.G., Effects of E. coli lipopolysaccharide on the telithromycin pharmacokinetics in rats: inhibition of metabolism via CYP3A. Antimicrob. Agents Chemother. 52: 1046-1051, 2008.

34. Yang, K.H., Jung, Y.S., Lee, D.Y., Lee, J.H., Kim, Y.C., Lee, M.G., Time-dependent effects of Klebsiella pnemoniae endotoxin (KPLPS) on the pharmacokinetics of theophylline in rats: return of the parameters in 96-hour KPLPS rats to the control levels. Drug Metab. Dispos. 36: 811-815, 2008 . 